\title{
Research Paper: \\ Heavy Metal Contaminations at Two Iranian Copper Mining Areas and the Remediation by Indigenous Plants
}

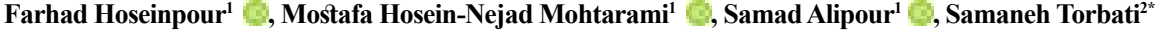

1. Department of Geology, Faculty of Science, Urmia University, Urmia, Iran.

2. Urmia Lake Research Institute, Urmia University, Urmia, Iran.

\begin{tabular}{|c|c|}
\hline $\begin{array}{l}\text { Use your device toscan } \\
\text { and read the artice online }\end{array}$ & How to cite this paper Hoseinpour F, Hosein-Nejad Mohtarami M, Alipour S, Torbati S. Heavy Metal Contaminations at \\
\hline & $\begin{array}{l}\text { Two Iranian Copper Mining Areas and the Remediation by Indigenous Plants. Iranian Journal of Toxicology. 2020; 14(2):81-92. } \\
\text { http://dx.doi.org/10.32598/ijt.14.2.501 }\end{array}$ \\
\hline 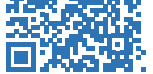 & dc) http://dx.doi.org/10.32598/ijt.14.2.501 \\
\hline
\end{tabular}

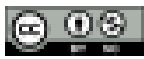

Article info:

Received: 01 Oct 2019

Accepted: 19 Feb 2020

Online Published: 01 Apr 2020

* Corresponding author:

Samaneh Torbati, PhD.

Address: Urmia Lake Research Institute, Urmia University, Urmia, Iran.

E-mail: samaneh.torbati@yahoo.com, s.torbati@urmia.ac.ir

\section{ABSTRACT}

Background: High concentrations of various heavy metals of mine tailings can easily contaminate the environment. Such materials need monitoring and remediation to prevent them from polluting the environment and food chain.

Methods: The concentrations of certain metals were evaluated in the soil samples at Sorkheh and Mazraeh copper mining areas in northwestern Iran, using three reliable pollution indices. We assessed the ability of three plants, Alhaji maurorum and Stachys inflata at Sorkheh mines, and Cirsium vulgare at Mazraeh mines, the dominant plants grown in those areas, in taking up the metals from the associated soils. The plant and soil samples were analyzed inductively by coupled plasma-mass spectrometry (ICP-MS).

Results: The results revealed that the soil samples at Sorkheh and Mazraeh mining areas were highly contaminated with As at CF values of 16.9 and 4.6, respectively. The soil samples from the two mining areas were moderately contaminated with $\mathrm{Pb}$ and $\mathrm{Zn}$. The data confirmed that A. maurorum and S. inflata had a good ability to accumulate $\mathrm{Cd}$, Mo and $\mathrm{Sc}$ from the soils in Sorkheh area. The other plant, C. vulgare, accumulated $\mathrm{Zn}$ and $\mathrm{Pb}$ at $1891 \mathrm{mg} / \mathrm{kg}$ and $18.6 \mathrm{mg} /$ $\mathrm{kg}$, respectively. The studied plants were good indicators of heavy metals contaminating the soils in these mining areas.

Conclusion: This study provided geochemical evidence about the heavy metals that contaminated the soils in the mining areas, and contributed new information about these toxic metals and their concentrations in the three plants and the soil samples.

Keywords: Heavy metals; Biogeochemistry; Native plants; Phytoextraction; Soil pollution indices

\section{Introduction}

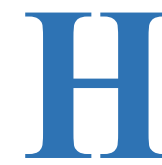

eavy metals are the major environmental pollutants, which emerged as a consequence of rapid industrialization [1]. Different physical, chemical and biological processes have been recently used for their monitoring and remediation in contaminated areas $[1,2]$. The cost involved and the environmental acceptability are the two key factors that should be considered in the selection and application of remediation technologies $[1,3]$. Phytoremediation, as an effective, economical and biological approach can be one of the practical strategies for monitoring and harvesting heavy metals from contaminated sites $[4,5]$. Metal concentrations detected in plant samples are reliable indices in selecting suitable and tolerant species [6-8].

The potentials of such plants as Dactylis glomerata [9], Polypogon fugax [10], and Viola principis [11] in 
accumulating $\mathrm{As}, \mathrm{Cu}, \mathrm{Cd}$, and $\mathrm{Ni}$ in their aerial parts have previously been confirmed. The accumulating plants cannot only be used for the bio-remediation of the polluted environments but some of them have been identified as useful indicators of metal mineralization [10].

Iran is one of the richest countries in mineral deposits, with many vast areas where the soils are contaminated with heavy metals due to leftover materials, i.e., mine tailings [9]. Oftentimes, there is not Studies have recommended the use of native plants as a sustainable strategy to resolve the environmental problems caused by mine tailings [10]. Often, there is not enough knowledge about the concentrations of various heavy metals in the plants grown over such polluted lands [11].

The two mining areas in northwest Iran, Sorkheh and Mazraeh, rich in skarn deposits, are the major sediment-hosted, stratiform areas with copper mines [12, 13] were selected for the purpose of the present study. Two plant species, Alhaji maurorum from the Fabaceae and Stachys inflata from Lamiaceae plant families were selected from the Sorkheh area. Also, Cirsium vulgare from the Asteraceae plant family was abundant in Mazraeh area. These three plants were selected to study their bioaccumulation potentials.

The aim of the present study was to investigate the heavy metal contaminations of the copper mining areas in northwestern Iran and to determine the potentials of the local plants for the absorption and/or remediation of the contaminations. The knowledge to be gained could confirm the plants' suitability for the remediation of the contaminated soils in the studied areas.

\section{Materials and Methods}

Mining Sites: Two copper mining sites, Mazareh and Sorkheh, in northwestern Iran were studied. Mazraeh skarn mine is located about $20 \mathrm{~km}$ north of Ahar in eastern Azerbaijan Province, northwest of Iran $\left(47^{\circ} 4^{\text {, }}\right.$ $\mathrm{E}$ and $\left.38^{\circ} 39^{\prime} \mathrm{N}\right)$. The other mining site, Sorkheh, is located near Marand in northwestern Iran (45 $26^{\circ} \mathrm{E}$ and $38^{\circ} 28^{\prime} \mathrm{N}$ ). In both areas, copper mineralization is evident by the abundant malachite-azurite staining on weathered rock surfaces. Figure 1 represents the maps of the studied areas.

Soil and Plant Sampling, Preparation and Characterization: In the spring of 2017, the soil and aerial plant samples were collected. These were indigenous plants from Sorkheh (Alhaji maurorum and Stachys inflata) and Mazraeh copper mines (Cirsium vulgare) (Figure 2). The soil samples were collected randomly from a depth of $30-40 \mathrm{~cm}$ around the rhizosphere of the plants. The soil samples were air-dried at room temperature, oven-dried at $100^{\circ} \mathrm{C}$ for $3 \mathrm{~h}$, then were ground and passed through a 2-mm mesh sieve. To determine the elemental contents, the soil samples were digested by an aqueous mixture of

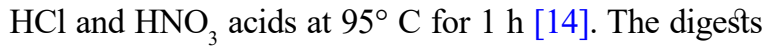
were analyzed, using HP Agilent 4500 ICP-MS (USA) at the laboratories of Zar Azma Company (Tehran, Iran).
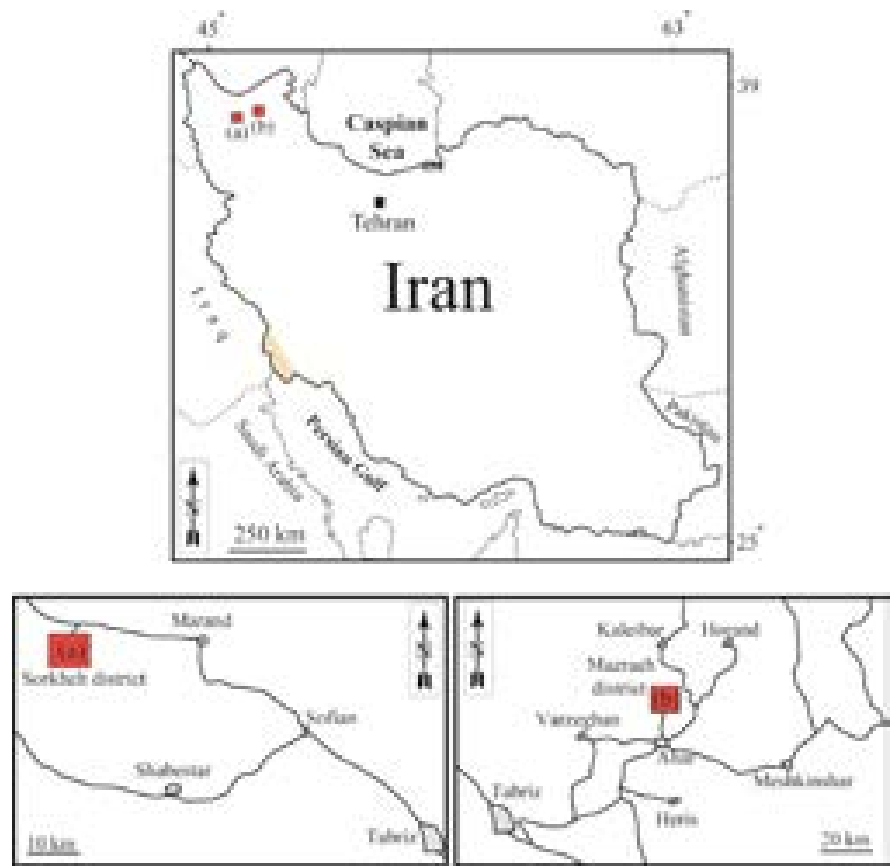

Figure 1. a. Map of the Sorkheh; and b. Mazraeh; mining areas in northwest of Iran 


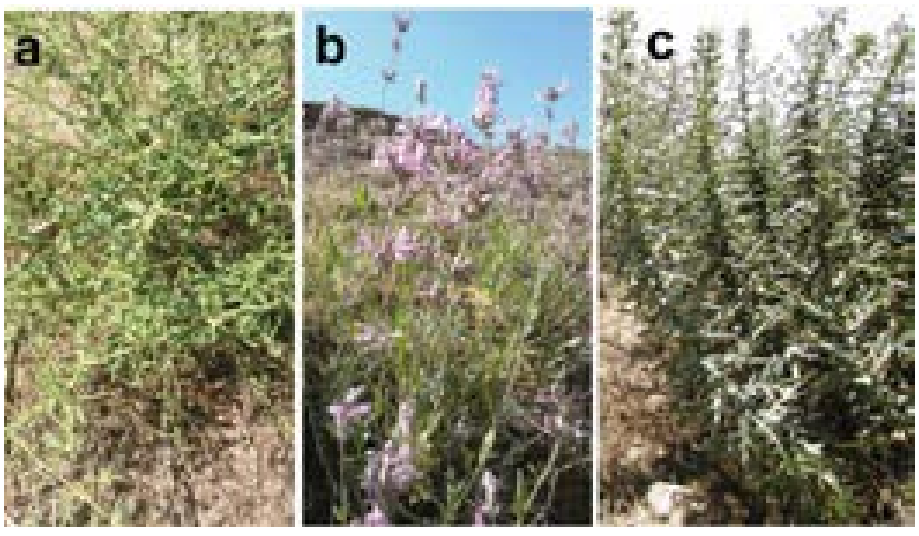

Figure 2. A. maurorum (a) and S. inflata (b) from Sorkheh, and, C. vulgare (c) from Mazraeh mining areas

The samples of the plants' aerial parts were washed with tap water followed by distilled water. They were dried at the room temperature for 10 days. The air-dried plant samples were digested in $\mathrm{HNO}_{3}$ for $1 \mathrm{hr}$; then were kept in the $\mathrm{HCl}-\mathrm{HNO}_{3}-\mathrm{H}_{2} \mathrm{O}$ mixture for $1 \mathrm{hr}$ at $95^{\circ} \mathrm{C}$ and analyzed on the ICP-MS apparatus [15].

Assessment of Soil Contaminations: In order to assess the extent of $\mathrm{Pb}, \mathrm{As}, \mathrm{Zn}, \mathrm{Cd}$, Mo and $\mathrm{Sc}$ contaminations in the soil samples from Sorkheh and Mazraeh areas, the following indices were used: Enrichment Factor (EF), Contamination Factor (CF) and geo-accumulation index $\left(\mathrm{I}_{\mathrm{geo}}\right)$. The EF was calculated based on the normalization of one metal content in the sample with respect to the reference concentration for that metal [16]. A reference element is one with a stable amount in different soil samples. Iron was used as a Reference Element (RE) for the determination of EF, as represented by Equation 1 below:

1. $E F=\left(C_{\text {mental }} / C_{R E}\right)$ in sample $/=\left(C_{\text {mental }} / C_{R E}\right)$ in the earth crust

The reported values, as the average crustal abundance of the metals, were used for the determination of each metal concentration and the amount of RE in the earth's crust [17-19]. When the value of EF is less than one, there is no enrichment for a given metal. There is a minor enrichment when the $\mathrm{EF}$ value falls between one and three. If the EF value rises between three and five, there is a moderate enrichment, and with the EF value being between 5 and 10, the enrichment is moderately severe. Also, at $\mathrm{EF}$ value of 10-25, the enrichment is severe, and an EF value of 25-50 represents a very severe enrichment. Finally, an EF value more than 50 represents the extremely severe enrichment [17-19].
The CF refers to the amount of metal in the sample as compared with the background concentration level, which is determined by Equation 2 as follows [18]:

2. $C F=C_{s} / C_{\text {background }}$.

The Taylor's average crustal abundance value was used as $\mathrm{C}_{\text {background }}$ for each metal in the soil samples [19]. With CF value being less than one, there was no metal contamination in the soil samples. But a $\mathrm{CF}<3$ represented a moderate contamination, $\mathrm{CF}<6$, there was a considerable contamination; and $\mathrm{CF}>6$ indicated a very high contamination for a given metal. The geo-accumulation index has been described by Muller [20] and is determined by Equation 3 as follows:

\section{3. $I_{\text {geo }}=\log _{2}[(\mathrm{Cn} /(1.5 \times \mathrm{Bn})]$}

Where $C n$ is the metal concentration in the soil, $\mathrm{Bn}$ refers to the average crustal abundance value for that metal, and 1.5 is a coefficient for the normalized background metal concentration. Based on the Muller's classification [20], when $\mathrm{I}_{\mathrm{geo}}<0$, the soil is not contaminated with a given metal. With $I_{\text {geo }}$ between $0-1$ refers to uncontaminated to slightly contaminated soil. Ranges between one and two represent a moderately polluted state, and 3-4 represents strongly polluted soils. $I_{\text {geo }}$ values between 4 and 5 represent strongly to extremely contaminated, and finally, $\mathrm{I}_{\text {geo }}>5$ represents extremely contaminated soils [20].

Biological Absorption Coefficient: The Biological Absorption Coefficient (BAC) was calculated to find the absorption intensity of the plants from their substrates, using Equation 4 as follows [21]:

$$
\text { 4. } B A C=C_{p} / C_{s}
$$


where $C_{p}$ is the concentration of an element in the plant and $C_{s}$ is the concentration of the same element in the soil samples. Based on the magnitude of BAC, the bioaccumulation capability of each plant for the element was classified into five groups as follows: $\mathrm{BAC}>10$ : very strong accumulation; 1-10: strong accumulation; 0.1-1.0: moderate accumulation; 0.01-0.1: weak accumulation; and 0.001-0.01: very weak accumulation [22].

Statistical Analyses: In order to identify the relationship between each element in the plant samples and their related soils, the Pearson's correlation analysis was performed using SPSS V. 24.

\section{Results}

Soil Pollution Indices: The results of the pollution indices, EF, CF, and $\mathrm{I}_{\text {geo }}$ from the sampling sites are shown in Tables 1, 2 and 3, respectively. Based on the Muller's classification for EF, the toxic element, As, was severely enriched in Sorkheh area (Table 1). In the soil samples from Mazraeh area, there was moderate enrichment of As, $\mathrm{Cd}$ and $\mathrm{Mo}$ and minor enrichment of $\mathrm{Pb}$ and $\mathrm{Zn}$.

As shown in Table 2, the mean CF values in Sorkheh area were in the order of $\mathrm{As}(16.9)>\mathrm{Pb}(1.6)>\mathrm{Zn}$ (1.1) $>\mathrm{Cd}(0.80)>\operatorname{Sc}(0.60)>$ Mo (0.07). Based on the
Hakanson's scale [18], the soil samples from Sorkheh area were considerably contaminated with As $(\mathrm{CF}>6)$, and moderately contaminated with $\mathrm{Pb}$ and $\mathrm{Zn}$. In contrast, the $\mathrm{CF}$ values for $\mathrm{Pb}, \mathrm{Zn}, \mathrm{Cd}$ and $\mathrm{Mo}$ in the soil samples from Mazraeh area fell between 3 and 5, indicating that they were moderately contaminated with those elements. The geo-accumulation index for the soil samples from Sorkheh area indicated that they were strongly contaminated with As $\left(\mathrm{I}_{\text {geo }}=3.3\right)$. The mean $\mathrm{I}_{\text {ge }}$ values for the soil samples from Mazraeh area were in the order of $\mathrm{As}>\mathrm{Cd}>\mathrm{Mo}>\mathrm{Pb}>\mathrm{Zn}>\mathrm{Sc}$ (Table 3 ).

\section{Distribution of elements in soil and plant uptakes}

Lead: The mean $\mathrm{Pb}$ concentration in the soil samples from Sorkheh and Mazraeh mines were 17.5 and 17.8 $\mathrm{mg} / \mathrm{g}$, respectively. Figures $3 \mathrm{~A}-3 \mathrm{C}$ illustrate the behavior of the three plant species in accumulating $\mathrm{Pb}$ from the soil samples.

Arsenic: The soil samples from Sorkheh and Mazraeh areas were contaminated with As at 30000 and $8000 \mu \mathrm{g} / \mathrm{kg}$ respectively (Tables 1-3). The mean contents for As in the plant samples were 1246, 2262 and $1180 \mu \mathrm{g} / \mathrm{kg}$ for A. maurorum, S. inflata and C. vulgare, respectively (Figures 3D-3F).

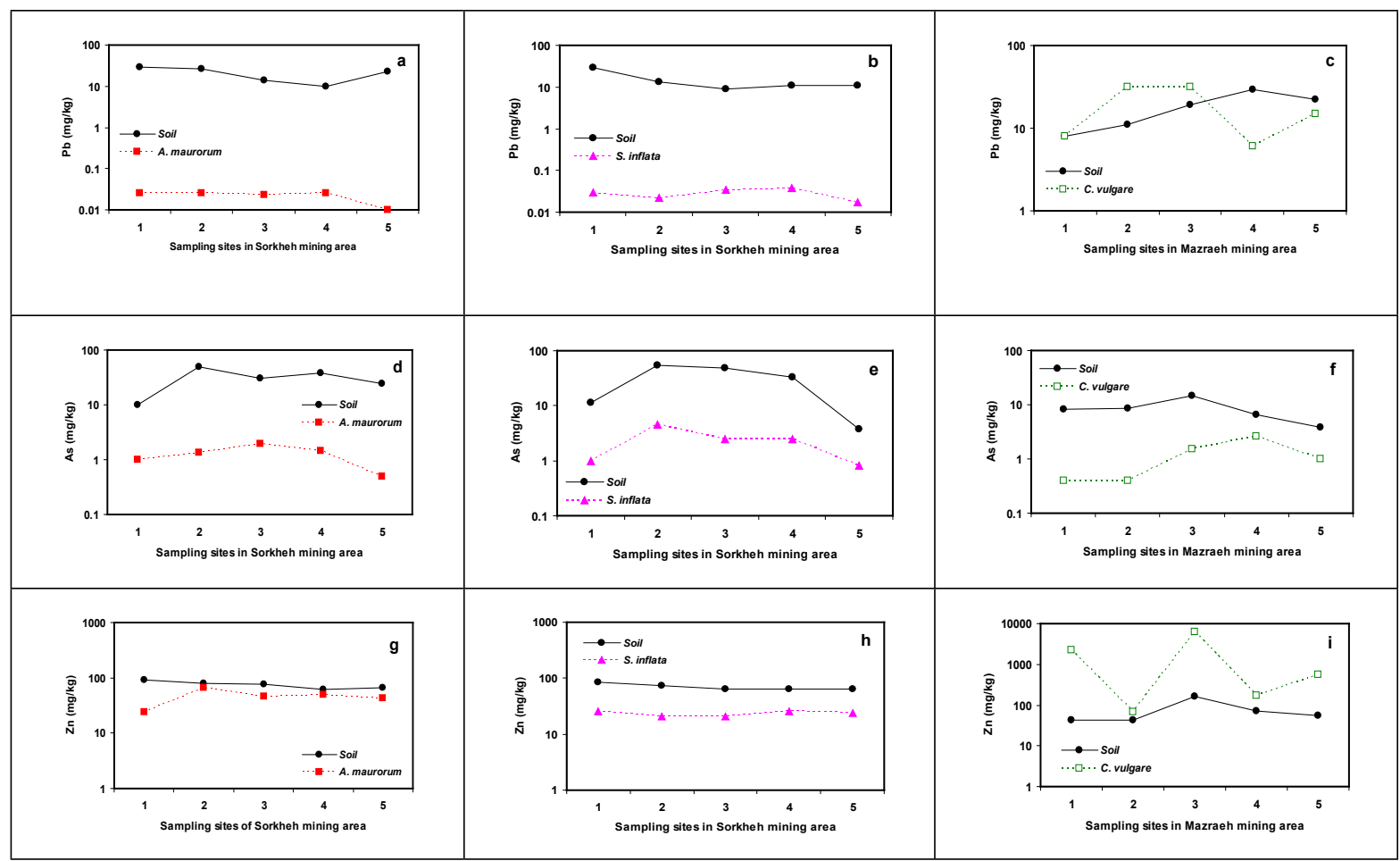

Figure 3. The concentrations of lead, arsenic and zinc in A. maurorum, S. inflata and C. vulgare plant samples. Metal Concentrations: $\mathrm{Pb}=\mathrm{a}, \mathrm{b} \& \mathrm{c} ; \mathrm{As}=\mathrm{d}, \mathrm{e} \& \mathrm{f}$; and $\mathrm{Zn}=\mathrm{g}$, h \& i. 
Table 1. EF index for metals in the soil samples from the two mining areas

\begin{tabular}{|c|c|c|c|c|c|c|}
\hline \multirow{2}{*}{ Sampling Site } & \multicolumn{2}{|c|}{$\mathrm{Cd}$} & \multicolumn{2}{|c|}{ Mo } & \multicolumn{2}{|c|}{ Sc } \\
\hline & Sorkheh & Mazraeh & Sorkheh & Mazraeh & Sorkheh & Mazraeh \\
\hline 1 & 0.57 & 2.68 & 0.079 & 1.06 & 0.989 & 0.85 \\
\hline 2 & 1.40 & 1.91 & 0.103 & 1.47 & 0.875 & 0.82 \\
\hline 3 & 1.49 & 2.26 & 0.104 & 3.25 & 0.915 & 0.46 \\
\hline 4 & 1.79 & 3.97 & 0.119 & 1.31 & 0.961 & 0.23 \\
\hline 5 & 0.31 & 5.50 & 0.041 & 9.88 & 0.221 & 0.26 \\
\hline \multirow{2}{*}{ EF (Mean) } & 1.11 & 3.27 & 0.09 & 3.39 & 0.8 & 0.52 \\
\hline & ME & ME & NE & ME & NE & NE \\
\hline \multirow{2}{*}{ Sampling Site } & \multicolumn{2}{|c|}{$\mathrm{Pb}$} & \multicolumn{2}{|c|}{ As } & \multicolumn{2}{|c|}{$\mathrm{Zn}$} \\
\hline & Sorkheh & Mazraeh & Sorkheh & Mazraeh & Sorkheh & Mazraeh \\
\hline 1 & 2.67 & 1.02 & 6.33 & 4.13 & 1.49 & 1.00 \\
\hline 2 & 2.92 & 0.79 & 38.63 & 2.61 & 1.60 & 0.95 \\
\hline 3 & 1.67 & 0.839 & 25.1 & 4.55 & 1.62 & 1.29 \\
\hline 4 & 1.43 & 1.319 & 38.23 & 4.86 & 1.59 & 1.64 \\
\hline 5 & 1.15 & 2.77 & 8.34 & 3.41 & 0.59 & 1.36 \\
\hline \multirow{2}{*}{ EF (Mean) } & 1.97 & 1.34 & 23.32 & 3.91 & 1.38 & 1.25 \\
\hline & ME & ME & SE & ME & ME & ME \\
\hline
\end{tabular}

NE: No Enrichment; ME: Minor Enrichment; ME: Moderate Enrichment; SE: Severe Enrichment.

Table 2. CF index for metals in the soil samples from the two mining areas

\begin{tabular}{ccccccc}
\hline \multirow{2}{*}{ Sampling Site } & \multicolumn{2}{c}{ Cd } & \multicolumn{2}{c}{ Mo } & \multicolumn{2}{c}{ Sc } \\
\cline { 2 - 7 } & Sorkheh & Mazraeh & Sorkheh & Mazraeh & Sorkheh & Mazraeh \\
\hline 1 & 0.5 & 3 & 0.07 & 0.67 & 0.86 & 0.53 \\
2 & 1 & 3.5 & 0.08 & 2.6 & 0.63 & 0.51 \\
\hline 3 & 1 & 4 & 0.07 & 2.07 & 0.62 & 0.51 \\
4 & 1 & 3 & 0.07 & 0.8 & 0.54 & 0.42 \\
\hline 5 & 0.5 & 3.5 & 0.07 & 5.6 & 0.35 & 0.46 \\
CF (Mean) & 0.8 & 3.4 & 0.07 & 2.35 & 0.6 & 0.48 \\
\hline Sampling Site & NC & MC-CC & NC & MC & NC & NC \\
\hline 1 & Sorkheh & Mazraeh & Sorkheh & Mazraeh & Sorkheh & Mazraeh \\
\hline 2 & 2.32 & 0.64 & 5.5 & 4.61 & 1.3 & 0.61 \\
\hline 3 & 2.08 & 0.88 & 27.5 & 4.78 & 1.15 & 0.6 \\
\hline 4 & 1.12 & 1.52 & 16.8 & 8.05 & 1.09 & 2.28 \\
\hline CF (Mean) & 0.8 & 2.32 & 21.3 & 3.67 & 0.89 & 1.04 \\
\hline
\end{tabular}

NC: Not Contaminated; MC: Moderately Contaminated; CC: Considerable Contaminated; VHC: Very High Contaminated. 
Table 3. $\mathrm{I}_{\text {geo }}$ index for metals in the soil samples from the two mining areas

\begin{tabular}{cccccccc}
\hline \multirow{2}{*}{ Sampling Site } & \multicolumn{2}{c}{ Cd } & \multicolumn{2}{c}{ Mo } & \multicolumn{2}{c}{ Sc } \\
\cline { 2 - 8 } & Sorkheh & Mazraeh & Sorkheh & Mazraeh & Sorkheh & Mazraeh \\
\hline 1 & -1.58 & 1 & -4.43 & -1.17 & -0.80 & -1.51 \\
2 & -0.58 & 1.22 & -4.35 & 0.8 & -1.27 & -1.55 \\
\hline 3 & -0.58 & 1.41 & -4.42 & 0.47 & -1.29 & -1.56 \\
4 & -0.58 & 1 & -4.49 & -0.91 & -1.48 & -1.84 \\
5 & -1.58 & 1.22 & -4.49 & 1.91 & -2.08 & -1.71 \\
$I_{\text {geo }}$ (Mean) & -0.98 & 1.17 & -4.44 & 0.21 & -1.38 & -1.63 \\
& NC & NC & NC & NC-MC & NC & NC \\
\hline
\end{tabular}

\begin{tabular}{cccccccc}
\hline \multirow{2}{*}{ Sampling Site } & \multicolumn{2}{c}{ Pb } & \multicolumn{2}{c}{ As } & \multicolumn{2}{c}{ Zn } \\
\cline { 2 - 7 } & Sorkheh & Mazraeh & Sorkheh & Mazraeh & Sorkheh & Mazraeh \\
\hline 1 & 0.63 & -1.23 & 1.8 & 1.62 & -0.21 & -1.29 \\
2 & 0.47 & -0.77 & 4.19 & 1.67 & -0.39 & -1.32 \\
3 & -0.42 & 0.02 & 3.49 & 2.42 & -0.47 & 0.61 \\
4 & -0.91 & 0.63 & 3.83 & 1.29 & -0.76 & -0.52 \\
5 & 0.29 & 0.23 & 3.16 & 0.53 & -0.67 & -0.96 \\
I & 0.013 & -0.22 & 3.31 & 1.51 & -0.50 & -0.70 \\
\hline
\end{tabular}

NC: Not Contaminated; MC: Moderately Contaminated; SC: Strongly Contaminated

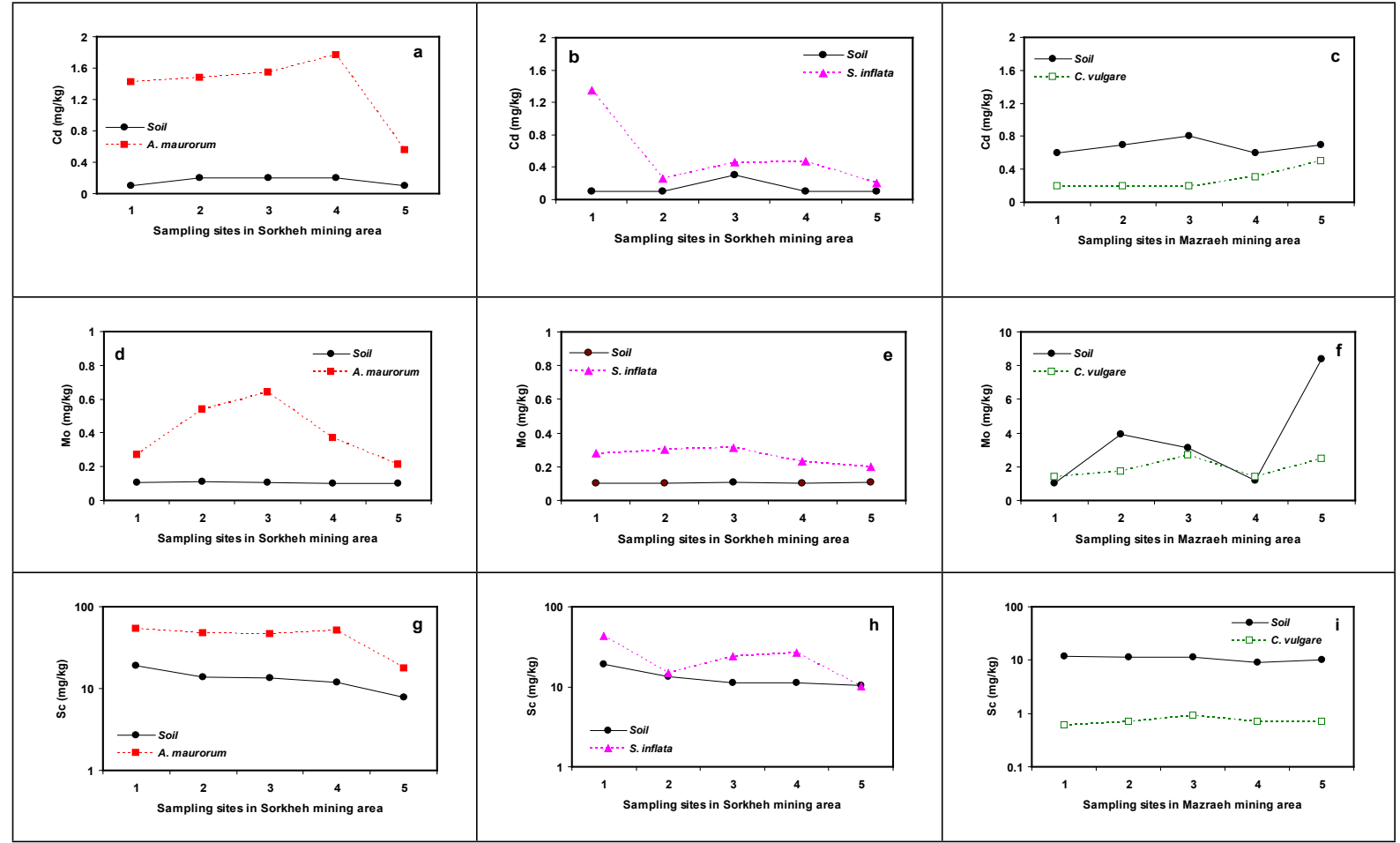

Figure 4. The concentrations of cadmium, molybdenum and scandium in the A. maurorum, $S$. inflata and C. vulgare plant samples. Metal Concentrations: $\mathrm{Cd}=\mathrm{a}, \mathrm{b} \& \mathrm{c} ; \mathrm{Mo}=\mathrm{d}$, e \& f; and $\mathrm{Sc}=\mathrm{g}$, h \& i. 
Table 4. Pearson's correlation coefficients for metals in the soil of Sorkheh mining area and the A. maurorum plant samples

\begin{tabular}{|c|c|c|c|c|c|c|c|c|c|c|c|c|c|}
\hline \multirow{2}{*}{ Variables } & & \multicolumn{6}{|c|}{ Soil } & \multicolumn{6}{|c|}{ A. maurorum } \\
\hline & & $\mathrm{Cd}$ & Mo & Sc & $\mathrm{Pb}$ & As & $\mathrm{Zn}$ & $\mathrm{Cd}$ & Mo & Sc & $\mathrm{Pb}$ & As & $\mathrm{Zn}$ \\
\hline \multirow{6}{*}{ Soil } & $\mathrm{Cd}$ & 1 & & & & & & & & & & & \\
\hline & Mo & 0.39 & 1 & & & & & & & & & & \\
\hline & $\mathrm{Sc}$ & -0.05 & 0.46 & 1 & & & & & & & & & \\
\hline & $\mathrm{Pb}$ & -0.63 & 0.44 & 0.39 & 1 & & & & & & & & \\
\hline & As & 0.82 & 0.44 & -0.35 & -0.35 & 1 & & & & & & & \\
\hline & $\mathrm{Zn}$ & -0.28 & 0.62 & 0.87 & 0.73 & -0.41 & 1 & & & & & & \\
\hline \multirow{6}{*}{ A. maurorum } & $\mathrm{Cd}$ & 0.72 & 0.32 & 0.57 & -0.42 & 0.34 & 0.17 & 1 & & & & & \\
\hline & Mo & 0.84 & 0.652 & 0.16 & -0.35 & 0.58 & 0.11 & 0.58 & 1 & & & & \\
\hline & Sc & 0.47 & 0.4 & 0.81 & -0.12 & 0.09 & 0.47 & $0.94 *$ & 0.43 & 1 & & & \\
\hline & $\mathrm{Pb}$ & 0.59 & 0.55 & 0.75 & -0.09 & 0.29 & 0.45 & $0.94 *$ & 0.54 & $0.97 * *$ & 1 & & \\
\hline & As & 0.85 & 0.41 & 0.30 & -0.57 & 0.42 & 0.06 & 0.80 & $0.91 *$ & 0.65 & 0.69 & 1 & \\
\hline & $\mathrm{Zn}$ & 0.74 & 0.45 & -0.44 & -0.26 & $0.98 * *$ & -0.41 & 0.17 & 0.55 & -0.06 & 0.14 & 0.32 & 1 \\
\hline
\end{tabular}

* Correlation was significant at $\mathrm{P}<0.05$ level (2-tailed).

** Correlation was significant at $\mathrm{P}<0.01$ level (2-tailed).

Table 5. Pearson's correlation coefficients among amount of metals in the soil samples of Sorkheh mining area and S. inflate branches.

\begin{tabular}{|c|c|c|c|c|c|c|c|c|c|c|c|c|c|}
\hline \multirow{2}{*}{\multicolumn{2}{|c|}{ Variables }} & \multicolumn{6}{|c|}{ Soil } & \multicolumn{6}{|c|}{ S. inflata } \\
\hline & & $\mathrm{Cd}$ & Mo & Sc & $\mathrm{Pb}$ & As & $\mathrm{Zn}$ & $\mathrm{Cd}$ & Mo & Sc & $\mathrm{Pb}$ & As & $\mathrm{Zn}$ \\
\hline \multirow{6}{*}{ Soil } & $\mathrm{Cd}$ & 1 & & & & & & & & & & & \\
\hline & Mo & 0.87 & 1 & & & & & & & & & & \\
\hline & Sc & -0.30 & -0.53 & 1 & & & & & & & & & \\
\hline & $\mathrm{Pb}$ & -0.38 & -0.56 & $0.97 * *$ & 1 & & & & & & & & \\
\hline & As & 0.45 & 0.26 & -0.23 & -0.45 & 1 & & & & & & & \\
\hline & $\mathrm{Zn}$ & -0.37 & -0.57 & $0.99 * *$ & $0.96 * *$ & -0.225 & 1 & & & & & & \\
\hline \multirow{6}{*}{ S. inflata } & $\mathrm{Cd}$ & -0.11 & -0.41 & $0.91^{*}$ & $0.92^{*}$ & -0.35 & 0.85 & 1 & & & & & \\
\hline & Mo & 0.54 & 0.27 & 0.38 & 0.17 & 0.72 & 0.36 & 0.27 & 1 & & & & \\
\hline & Sc & 0.004 & -0.39 & 0.80 & 0.8 & -0.19 & 0.73 & $0.96^{* *}$ & 0.32 & 1 & & & \\
\hline & $\mathrm{Pb}$ & 0.43 & -0.003 & 0.02 & -0.04 & 0.36 & -0.08 & 0.30 & 0.29 & 0.56 & 1 & & \\
\hline & As & 0.09 & -0.02 & -0.18 & -0.38 & $0.92^{*}$ & -0.13 & -0.43 & 0.56 & -0.33 & 0.10 & 1 & \\
\hline & $\mathrm{Zn}$ & -0.56 & -0.69 & 0.40 & 0.55 & -0.7 & 0.36 & 0.59 & -0.56 & 0.59 & 0.25 & -0.63 & 1 \\
\hline
\end{tabular}

${ }^{*}$ Correlation is significant at $\mathrm{P}<0.05$ level (2-tailed). ${ }^{*}$ Correlation is significant at $\mathrm{P}<0.01$ level (2-tailed).

Zinc: The mean $\mathrm{Zn}$ contents in the plant samples were 45.8 and $23.2 \mathrm{mg} / \mathrm{kg}$ for $A$. maurorum and $S$. inflata, respectively (Figures $3 \mathrm{G} \& 3 \mathrm{H}$ ). In contrast, the mean $\mathrm{Zn}$ content in the plant samples from C. vulgare was 1891 $\mathrm{mg} / \mathrm{kg}$ (Figure 3I).

Cadmium: The mean Cd contents in the soil samples from Sorkheh and Mazraeh mining areas were 0.15 and $0.70 \mathrm{mg} / \mathrm{kg}$, respectively. The elemental mean contents of $\mathrm{Cd}$ in A. maurorum, $S$. inflata and $C$. vulgare plant samples were approximately $1.35,0.55$ and $0.30 \mathrm{mg} / \mathrm{kg}$, re- spectively. Considering the lack of $\mathrm{Cd}$ in the soil samples from the Sorkheh mines (Tables 1-3), its contents in the plant samples were higher than that for the background contents in all of the five sampling sites (Figures 4A \& 4B) and C. vulgare in the Mazraeh area acted as an excluder plant (Figure 4C).

Molybdenum: The mean Mo concentrations in the copper mining areas were 0.1 and $3.5 \mathrm{mg} / \mathrm{kg}$ for Sorkheh and Mazareh, respectively. The Mo concentrations in all plant samples from Sorkheh area $(0.2-0.6 \mathrm{mg} / \mathrm{kg})$ were 
Table 6. Pearson's correlation coefficients for metals among the soils of Mazraeh mining area and C. vulgare branches

\begin{tabular}{|c|c|c|c|c|c|c|c|c|c|c|c|c|c|}
\hline \multirow{2}{*}{\multicolumn{2}{|c|}{ Variables }} & \multicolumn{6}{|c|}{ Soil } & \multicolumn{6}{|c|}{ S. inflata } \\
\hline & & Cd & Mo & Sc & $\mathrm{Pb}$ & As & $\mathrm{Zn}$ & Cd & Mo & Sc & $\mathrm{Pb}$ & As & $\mathrm{Zn}$ \\
\hline \multirow{6}{*}{ Soil } & $\mathrm{Cd}$ & 1 & & & & & & & & & & & \\
\hline & Mo & 0.44 & 1 & & & & & & & & & & \\
\hline & Sc & 0.32 & -0.14 & 1 & & & & & & & & & \\
\hline & $\mathrm{Pb}$ & -0.01 & 0.16 & $-0.93 *$ & 1 & & & & & & & & \\
\hline & As & 0.61 & -0.43 & 0.54 & -0.24 & 1 & & & & & & & \\
\hline & $\mathrm{Zn}$ & 0.71 & -0.11 & 0.05 & 0.32 & 0.79 & 1 & & & & & & \\
\hline \multirow{6}{*}{ S. inflata } & $\mathrm{Cd}$ & -0.05 & 0.79 & -0.61 & 0.54 & -0.75 & -0.24 & 1 & & & & & \\
\hline & Mo & $0.89 *$ & 0.67 & 0.09 & 0.2 & 0.32 & 0.65 & 0.35 & 1 & & & & \\
\hline & Sc & 0.87 & 0.13 & 0.03 & 0.33 & 0.72 & $0.93 *$ & -0.14 & 0.76 & 1 & & & \\
\hline & $\mathrm{Pb}$ & 0.86 & 0.25 & 0.52 & -0.30 & 0.63 & 0.45 & -0.35 & 0.56 & 0.67 & 1 & & \\
\hline & As & -0.10 & -0.24 & -0.8 & $0.92^{*}$ & 0.01 & 0.43 & 0.18 & -0.01 & 0.35 & -0.32 & 1 & \\
\hline & $\mathrm{Zn}$ & 0.65 & -0.19 & 0.45 & -0.12 & 0.87 & 0.88 & -0.41 & 0.58 & 0.74 & 0.43 & 0.04 & 1 \\
\hline
\end{tabular}

*Correlation was significant at $\mathrm{P}<0.05$ level (2-tailed)

more than those found in the soil samples $(0.10-0.11 \mathrm{mg} /$ $\mathrm{kg}$ ) (Figures 4D \& 4E). The mean concentration of Mo in the $C$. vulgare plant samples $(1.94 \mathrm{mg} / \mathrm{kg})$ was less than that detected in the soil samples from Mazraeh area (3.54 $\mathrm{mg} / \mathrm{kg}$ ) (Figure 4F).

Scandium: The average concentration of Sc in the soil samples from Sorkheh and Mazraeh copper mines were approximately 13 and $11 \mathrm{mg} / \mathrm{kg}$, respectively. The Sc contents in the plant samples of the two species were higher than those found in the background soil samples (Figures $4 \mathrm{G} \& 4 \mathrm{H})$. The mean concentrations of Sc in A. maurorum and $S$. inflata samples from Sorkheh area were 43.4 and $23.8 \mathrm{mg} / \mathrm{kg}$, respectively. In contrast, the amount of Sc in the soil samples from Mazareh area was about 10-fold higher than that in the samples of $C$. vulgare (Figure 4I).

Biological Absorption Potential: In Sorkheh area, Cd, Mo, and Sc were accumulated in the plants and their
BAC values were more than one (Figure 5). The potential of A. maurorum for the uptake of the above elements were 8.7, 3.9 and 3.3, respectively. These amounts for $S$. inflata were 4.9, 1.6 and 2.8, respectively. Conversely in Mazraeh area, the average BAC values for $\mathrm{Zn}$ and $\mathrm{Pb}$ were 21.4 and 1.3, respectively (Figure 5).

Correlation between Metal in the Soil and Plant Samples: Tables 4-6 compare the metal contents in the soils and plant samples. As seen in Table 4, there were positive correlations between the $\mathrm{Cd}, \mathrm{Sc}$, Mo and As concentrations in the soil and the A. maurorum plant samples from Sorkheh area. Moreover, the $\mathrm{Cd}$ content correlated significantly and positively $(R: 0.94)$ with those of $\mathrm{Sc}$ and $\mathrm{Pb}$ in the same plant samples. A synergistic relation between the $\mathrm{Cd}$ and $\mathrm{Pb}$ contents has been reported previously [23]. The correlations between the plants' content ratios of Mo:As and Sc:Pb were remarkably positive (Table 4).

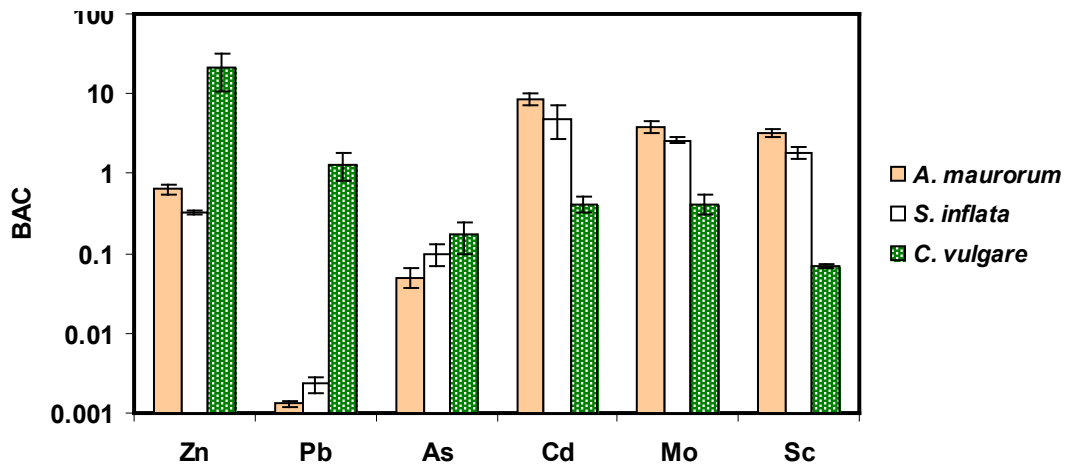

Figure 5. Comparison of BAC mean values of the heavy metals in A. maurorum, S. inflata and C. vulgare plant samples 
As shown in Table 4, there was a positive correlation between the plant samples' Mo and $\mathrm{Zn}$ contents with the amounts in the soil samples from Mazraeh area $(R$ : 0.666 and 0.876 , respectively. According to the data in Table 5, the correlations between the Mo, Sc, As and $\mathrm{Pb}$ contents in the soil samples from Sorkheh area and the $S$. inflata samples were positive, and that for As was significantly positive $(R: 0.92)$. Further, similar positive correlations were found for $\mathrm{Pb}$ in the soil and $\mathrm{Cd}$ in the plant ( $R:$ 0.92). Moreover, the relationships between the content ratios of $\mathrm{Cd}$ in the soil and Mo in the plant $(R$ : $0.89), \mathrm{Pb}$ in the soil to As in the plant (R: 0.92) and $\mathrm{Zn}$ in the soil to $\mathrm{Sc}$ in the plant $(R: 0.93)$ were significantly positive (Table 6).

\section{Discussion}

Problems with the wastes management of contaminated soils and water from mines have become the major causes of ongoing environmental pollution with heavy metals. According to the literature, plants cultivated in contaminated soils accumulate higher concentrations of toxic metals than those grown in uncontaminated lands [24]. Therefore, the study of the plants and soil relationship can lead to the development of practical remediation protocols to save the environment and industrial lands.

Lead: Lead concentrations in the soils and vegetations have increased in modern times. The mean contamination of $\mathrm{Pb}$ in various mining areas is estimated to be 27 $\mathrm{mg} / \mathrm{kg}$ worldwide [23]. It has been reported that the $\mathrm{Pb}$ content in the plants grown in contaminated lands, such as mining and mineralized areas, is between 63 and 232 $\mathrm{mg} / \mathrm{kg}$ [25]. According to varying responses of plants to elements as described by Baker [26], A. maurorum and $S$. inflata are known as excluder plants for taking up lead from Sorkheh area. This suggests that the $\mathrm{Pb}$ contents in the two plants were approximately constant despite its varying content in the soil. In contrast, $C$. vulgare content of $\mathrm{Pb}$ varied depending on its content in the soil samples from the Mazraeh area.

Arsenic: Is a highly toxic metalloid and the most abundant element in the Earth's crust, with a mean concentration of approximately $3 \mathrm{mg} / \mathrm{kg}$ [27]. In another study, the concentrations of As in the aerial parts of Pteris vitatta ranged $0.5-80 \mu \mathrm{g} / \mathrm{kg}$ [27]. This was the first arsenic hyper-accumulator plant discovered that grows in uncontaminated soils. The mean concentration of As in our plant samples was slightly higher than that reported in the former plant. These plants are known as the As excluders.
Zinc: Among the three examined plants, $C$. vulgare showed a good performance in accumulating $\mathrm{Zn}$ from the soil in Mazraeh area. It was about 25-fold higher than that detected in the soil. In most plant species, the concentration is under $50 \mathrm{mg} / \mathrm{kg}$ [23], which is consistent with that documented for A. maurorum and $S$. inflata samples.

Molybdenum: The mean concentration of Mo in the Earth's crust has been reported at $1.5 \mathrm{mg} / \mathrm{kg}$. The phytoavailability of Mo in soil is influenced by such factors as drought, soil $\mathrm{pH}$, texture, and plants growing on it [28]. This element plays an important role in the nitrogen and sulfur metabolism in plants, and the biosynthesis of plant hormones and proteins [29]. We noted that the plants in both mining areas had absorbed Mo as they needed irrespective of its content in the soil.

Scandium: The mean content of Sc in the Earth's crust worldwide has been estimated between $0.8-28 \mathrm{mg} / \mathrm{kg}$. The mean concentration of scandium in the soil samples from Sorkheh and Mazraeh areas were higher than those reported globally. Although there is not much information available about the Sc concentrations in plants, the previously reported amounts by one study in various plants were below $0.02 \mathrm{mg} / \mathrm{kg}$ [23]. The two plants from Sorkheh area showed a good performance in taking up Sc from the associated soils.

The association between elements in various soils and/ or plants is due to multiple variables, such as $\mathrm{pH}$, soil organic materials, bio-availability of the elements, plant age, and depth of the plant roots $[6,30]$. The relationship may also be linked to the ionic competitions in the soil particles, and the properties of the surface cells in the roots and their exudates. Plants can use two different strategies in response to elements: either exclude or accumulate them. If the element concentration in the plant reflects that in the soil, the plant is termed an "indicator" $[8,26]$ $[8,26]$. There is a linear relationship, i.e., positive correlation, between the elemental concentrations in the indicator plants and the soil they are growing on. In this study, it was confirmed that A. maurorum can be used as a useful indicator of Cd, Sc and Mo mineralization. Also, S. inflata may be an appropriate indicator plant for As. Moreover, the amounts of Mo and $\mathrm{Zn}$ in the samples of $C$. vulgare can be used as a useful indicator of Mo and $\mathrm{Zn}$ mineralization.

\section{Limitation of the Study}

We were limited in our laboratory set up to evaluate the soil samples' $\mathrm{pH}$, electrical conductivity and organic contents. In future studies, the analyses of these param- 
eters could provide additional evidence in support of the examined plants' behaviors leading to the accumulation of the heavy metals.

\section{Conclusions}

The soil contents of $\mathrm{Pb}, \mathrm{As}, \mathrm{Zn}, \mathrm{Cd}$, Mo and $\mathrm{Sc}$ from Sorkheh and Mazraeh copper mining areas were determined based on three pollution indices: EF, CF, and $\mathrm{I}_{\text {geo }}$. Accordingly, the soil samples from the two mining areas were considerably contaminated with As. According to the probed bio-accumulation potentials of the indigenous plants in two areas, A. maurorum and S. inflata, possessed a high ability to uptake $\mathrm{Cd}$, Mo and Sc. The third plan, C. vulgare, notably accumulated $\mathrm{Zn}$ and $\mathrm{Pb}$. Based on Pearson's correlation among the concentrations of the elements in the aerial part of the plants and those in the associated soil samples, there was a linear relationship between the As concentrations in the soil and that detected in the $S$. inflata plant samples, making this plant a useful indicator for As. There were positive relationships between $\mathrm{Cd}$, Sc and Mo contents in A. marorum and the associated soil samples. The relationships among $\mathrm{Mo}, \mathrm{Sc}$ and $\mathrm{Pb}$ contents in S. inflata and the soil samples were positive. The $\mathrm{Zn}$ and Mo contents in the $C$. vulgare samples were positively related to those detected in the associated soil samples.

\section{Ethical Considerations}

\section{Compliance with ethical guidelines}

The study is about interaction between soil and native plants which did not involve animals and human subjects. All ethical principles of plants studies were applied in this research.

\section{Funding}

This research did not receive any specific grant from funding agencies in the public, commercial, or not-forprofit sectors.

\section{Author's contributions}

Investigation, performing experiments: Farhad Hoseinpour, and Mostafa Hosein-Nejad Mohtarami; Designing methodology, writing, review and editing: Samaneh Torbati; Cowriting the paper: Samad Alipour.

\section{Conflict of interest}

The authors declared no conflict of interests.

\section{Acknowledgements}

The authors wish to thank the administration and the staff of the Department of Geology, Faculty of Science, Urmia University, Urmia, Iran, for generously supporting this study.

\section{References}

[1] Khalid S, Shahid M, Niazi NK, Murtaza B, Bibi I, Dumat C. A comparison of technologies for remediation of heavy metal contaminated soils. J Geochem Explor. 2017; 182:24768. [DOI:10.1016/j.gexplo.2016.11.021]

[2] Liang HM, Lin TH, Chiou JM, Yeh KC. Model evaluation of the phytoextraction potential of heavy metal hyperaccumulators and non-hyperaccumulators. Environ Pollut. 2009; 157(6):1945-52. [DOI:10.1016/j.envpol.2008.11.052] [PMID]

[3] Ansari AA, Gill SS, Gill R, Lanza GR, Newman L, editors. Phytoremediation: Management of environmental contaminants. Basel: Springer International Publishing; 2015. [DOI:10.1007/978-3-319-10395-2]

[4] Rai PK. Heavy metal phytoremediation from aquatic ecosystems with special reference to macrophytes. Crit Rev Environ Sci Technol. 2009; 39(9):697-753. [DOI:10.1080/10643380801910058]

[5] Sasmaz M, Sasmaz A. The accumulation of strontium by native plants grown on Gumuskoy mining soils. J Geochem Explor. 2017; 181:236-42. [DOI:10.1016/j.gexplo.2017.08.001]

[6] Sheoran V, Sheoran AS, Poonia P. Factors affecting phytoextraction: A review. Phedosphere. 2016; 26(2):148-66. [DOI:10.1016/S1002-0160(15)60032-7]

[7] Krämer U. Metal hyperaccumulation in plants. Annu Rev Plant Biol. 2010; 61:517-34. [DOI:10.1146/annurev-arplant-042809-112156] [PMID]

[8] Baker AJM, Brooks RR. Terrestrial higher plants which hyperaccumulate metallic elements: A review of their distribution, ecology and phytochemistry. Biorecovery. 1989; 1:81126. https://www.researchgate.net/publication/247713966

[9] Hosseini SM, Rezazadeh M, Salimi A, Ghorbanli M. Distribution of heavy metals and arsenic in soils and indigenous plants near an iron ore mine in northwest Iran. Acta Ecol Sin. 2018; 38(5):363-7. [DOI:10.1016/j.chnaes.2018.02.004]

[10] Ghaderian SM, Ghotbi Ravandi AA. Accumulation of copper and other heavy metals by plants growing on Sarcheshmeh copper mining area, Iran. J Geochem Explor. 2012; 123:25-32. [DOI:10.1016/j.gexplo.2012.06.022]

[11] Wan X, Lei M, Yang J. Two potential multi-metal hyperaccumulators found in four mining sites in Hunan Province China. CATENA. 2017; 148(1):67-73. [DOI:10.1016/j.catena.2016.02.005]

[12] Rajabpour Sh, Abedini A, Alipour S, Lehmann B, Jiang SY Geology and geochemistry of the sediment-hosted Chesh- 
meh-Konan redbed-type copper deposit, NW Iran. Ore Geol Rev. 2017; 86:154-71. [DOI:10.1016/j.oregeorev.2017.02.013]

[13] Mollai H, Sharma R, Pe-Piper G. Copper mineralization around the Ahar batholith, north of Ahar (NW Iran): Evidence for fluid evolution and the origin of the skarn ore deposit. Ore Geol Rev. 2009; 35(3-4):401-14. [DOI:10.1016/j. oregeorev.2009.02.005]

[14] Torbati S, Alipour S, Rostami M, Hajializadeh S. Bio-accumulation of major, trace, and rare earth elements by two Astragalus species grown on Agh-Dareh and Zarshouran gold deposits, Takab, NW Iran. J Min Environ. 2018; 9(2):417-29. [DOI:10.22044/JME.2018.6995.1539]

[15] Samadi M, Torbati S, Alipour S. Metal(loid) uptake of Sonchus oleraceus grown around Cheshmeh-Konan copper deposit, NW Iran. J Min Environ. 2019; 10(2):517-28. [DOI:10.22044/JME.2019.7935.1659]

[16] Darvish Bastami K, Bagheri H, Haghparast S, Soltani F, Hamzehpoor A, Darvish Bastami M. Geochemical and geo-statistical assessment of selected heavy metals in the surface sediments of the Gorgan Bay, Iran. Mar Pollut Bull. 2012; 64(12):2877-84. [DOI:10.1016/j.marpolbul.2012.08.015] [PMID]

[17] Anbuselvan N, Senthil Nathan D, Sridharan M. Heavy metal assessment in surface sediments off Coromandel Coast of India: Implication on marine pollution. Mar Pollut Bull. 2018; 131:712-26. [DOI:10.1016/j.marpolbul.2018.04.074] [PMID]

[18] Hakanson L. An ecological risk index for aquatic pollution control. A sedimentological approach. Water Res. 1980; 14(8):975-1001. [DOI:10.1016/0043-1354(80)90143-8]

[19] Taylor SR. Abundance of chemical elements in the continental crust: A new table. Geochim Cosmochim Acta. 1964; 28(8):1273-85. [DOI:10.1016/0016-7037(64)90129-2]

[20] Hasan AB, Kabir S, Selim Reza AHM, Nazim Zaman M, Ahsan A, Rashid M. Enrichment factor and geo-accumulation index of trace metals in sediments of the ship breaking area of Sitakund Upazilla (Bhatiary-Kumira), Chittagong, Bangladesh. J. Geochem. Explor. 2013; 125:130-7. [DOI: 10.1016/j. gexplo.2012.12.002]

[21] Kovalevsky AL. Barrier-free biogeochemical prospecting. In: Brooks RR, Dunn CE, Hall EM. Biological Systems in Mineral Exploration and Processing. Hertfordshire: Ellis Horwood; 1995. 283-300. https://books.google.com/ books?id=455PAQAAIAAJ\&dq

[22] Farjandi F, Faiziev A, Fozilov M, Bastani H, Soleiman $\mathrm{S}$. The application of biogeochemistry for gold exploration in the Masjed-Daghi, Julfa, NW Iran. Arab. J. Geosci. 2013; 6:1435-46. [DOI:10.1007/s12517-011-0448-7]

[23] Kabata-Pendias A. Trace elements in soils and plants. $4^{\text {th }}$ ed. Boca Raton: CRC Press; 2010. [DOI:10.1201/b10158]

[24] Liphadzi MS, Kirkham MB, Musil CF. Phytoremediation of soil contaminated with heavy metals: A technology for rehabilitation of the environment. S Afr J Bot. 2005; 71(1):24-37. [DOI:10.1016/S0254-6299(15)30145-9]

[25] Roberts TM, Gizyn W, Hutchinson TC. Lead contamination of air, soil, vegetation and people in the vicinity of secondary lead smelters. In: Hemphill DD, Hemphill DD. Proceedings of $8^{\text {th }}$ annual conference on trace substances in environmental health; 1974 Jun 11. Columbia, MO, USA, 1974. https:// www.osti.gov/biblio/5874274

[26] Baker AJM. Accumulators and excluders-strategies in the response of plants to heavy metals. J Plant Nutr. 1981; 3(14):643-54. [DOI:10.1080/01904168109362867]

[27] Zhao FJ, McGrath SP, Meharg AA. Arsenic as a food chain contaminant: Mechanisms of plant uptake and metabolism and mitigation strategies. Annu Rev PLant Biol. 2010; 61:53559. [DOI:10.1146/annurev-arplant-042809-112152] [PMID]

[28] Zakikhani H, Khanif YM, Anuar AR, Radziah O, Soltangheisi A. Effects of different levels of molybdenum on uptake of nutrients in rice cultivars. Asian J Crop Sci. 2014; 6(3):23644. [DOI:10.3923/ajcs.2014.236.244]

[29] Alam F, Kim TY, Kim SY, Alam SS, Pramanik P, Kim PJ et al. Effect of molybdenum on nodulation, plant yield and nitrogen uptake in hairy vetch (Vicia villosa Roth). Soil Sci Plant Nutr. 2015; 61(4):664-75. [DOI:10.1080/00380768.2015. 1030690]

[30] Sarwar N, Imran M, Shaheen MR, Ishaque W, Kamran MA, Matloob A, et al. Phytoremediation strategies for soils contaminated with heavy metals: Modifications and future perspectives. Chemosphere. 2017; 171:710-21. [DOI:10.1016/j. chemosphere.2016.12.116] [PMID] 
This Page Intentionally Left Blank 